\title{
Positional and functional mapping of a neuroblastoma differentiation gene on chromosome I I
}

\author{
Katleen De Preter ${ }^{* 1}$, Jo Vandesompele ${ }^{\dagger 1}$, Björn Menten ${ }^{1}$, Philippa Carr ${ }^{2}$, \\ Heike Fiegler ${ }^{2}$, Anders Edsjö ${ }^{3}$, Nigel P Carter ${ }^{2}$, Nurten Yigit ${ }^{1}$, Wim Waelput ${ }^{4}$, \\ Nadine Van Roy ${ }^{1}$, Scott Bader ${ }^{5}$, Sven Påhlman ${ }^{3}$ and Frank Speleman ${ }^{1}$
}

Address: ${ }^{1}$ Center for Medical Genetics, Ghent University Hospital MRB 2nd floor, De Pintelaan 185, B-9000 Ghent, Belgium, ${ }^{2}$ The Wellcome Trust Sanger Institute, Wellcome Trust Genome Campus, Hinxton, Cambridge CB10 1SA, United Kingdom, ${ }^{3}$ Department of Laboratory Medicine, Molecular Medicine, Lund University, University Hospital MAS, S-20502 Malmö, Sweden, ${ }^{4}$ Department of Pathological Anatomy, Ghent University Hospital BLOK A, De Pintelaan 185, B-9000 Ghent, Belgium and ${ }^{5}$ Sir Alastair Currie Cancer Research U.K. Laboratories, Division of Pathology, Molecular Medicine Centre, University of Edinburgh, Crewe Road, Edinburgh EH4 2XU, United Kingdom

Email: Katleen De Preter* - katleen.depreter@ugent.be; Jo Vandesompele - joke.vandesompele@ugent.be; Björn Menten - bjorn.menten@ugent.be; Philippa Carr - pyc@sanger.ac.uk; Heike Fiegler - heike@sanger.ac.uk; Anders Edsjö - Anders.Edsjo@molmed.mas.lu.se; Nigel P Carter - npc@sanger.ac.uk; Nurten Yigit - nurten.yigit@ugent.be; Wim Waelput - wim.waelput@ugent.be; Nadine Van Roy - nadine.vanroy@ugent.be; Scott Bader - s.bader@ed.ac.uk; Sven Påhlman - Sven.Pahlman@molmed.mas.lu.se; Frank Speleman - franki.speleman@ugent.be

* Corresponding author †Equal contributors

Published: 06 July 2005

BMC Genomics 2005, 6:97 doi:10.1186/|47|-2/64-6-97
Received: 04 March 2005

Accepted: 06 July 2005

This article is available from: http://www.biomedcentral.com/I47/-2/64/6/97

(C) 2005 De Preter et al; licensee BioMed Central Ltd.

This is an Open Access article distributed under the terms of the Creative Commons Attribution License (http://creativecommons.org/licenses/by/2.0), which permits unrestricted use, distribution, and reproduction in any medium, provided the original work is properly cited.

\begin{abstract}
Background: Loss of chromosome I I q defines a subset of high-stage aggressive neuroblastomas. Deletions are typically large and mapping efforts have thus far not lead to a well defined consensus region, which hampers the identification of positional candidate tumour suppressor genes. In a previous study, functional evidence for a neuroblastoma suppressor gene on chromosome II was obtained through microcell mediated chromosome transfer, indicated by differentiation of neuroblastoma cells with loss of distal I I q upon introduction of chromosome II. Interestingly, some of these microcell hybrid clones were shown to harbour deletions in the transferred chromosome II. We decided to further exploit this model system as a means to identify candidate tumour suppressor or differentiation genes located on chromosome II.
\end{abstract}

Results: In a first step, we performed high-resolution arrayCGH DNA copy-number analysis in order to evaluate the chromosome II status in the hybrids. Several deletions in both parental and transferred chromosomes in the investigated microcell hybrids were observed. Subsequent correlation of these deletion events with the observed morphological changes lead to the delineation of three putative regions on chromosome II: I Iq25, I Ip I3->II I I5. I and II I I5.3, that may harbour the responsible differentiation gene.

Conclusion: Using an available model system, we were able to put forward some candidate regions that may be involved in neuroblastoma. Additional studies will be required to clarify the putative role of the genes located in these chromosomal segments in the observed differentiation phenotype specifically or in neuroblastoma pathogenesis in general. 


\section{Background}

In addition to the well known group of high stage neuroblastomas with MYCN amplification and 1p-deletion, a second genetic subgroup of aggressive neuroblastomas has been delineated. This subgroup is characterised by the presence of $11 \mathrm{q}$-deletions, often in association with $3 \mathrm{p}$ deletions [1-5]. Both subgroups typically present with 17q-gain or a normal chromosome 17 copy number, which are the strongest independent genetic indicators of poor prognosis [6]. Deletions of 11q mostly affect a large distal part of the long arm. Only a few small deletions have been identified which delineated a tentative SRO (shortest region of overlap) at 11q23 between markers D11S1340 and D11S1299, encompassing a region of approximately $3 \mathrm{Mb}$ [7]. More recently however, a neuroblastoma patient was reported with a constitutional 11q14.1-11q23.3 deletion that did not overlap with the proposed SRO [8]. Consequently, the presumed localisation of the $11 \mathrm{q}$ neuroblastoma tumour suppressor gene (or genes) remains ill defined, thus hampering the selection of positional candidate genes. For the $11 \mathrm{q} 23$ region we proposed SDHD as a putative candidate neuroblastoma tumour suppressor, but only two bona fide mutations could be identified[9].

In addition to the observed losses of $11 \mathrm{q}$ in neuroblastoma, the existence of a tumour suppressor gene on $11 \mathrm{q}$ has also been supported by functional evidence obtained by microcell mediated chromosome 11 transfer (MMCT) experiments [10]. Although these studies were initially aimed at investigating the role of chromosome 1p in tumour suppression, the control chromosome 11 transfer experiment unexpectedly produced clones with morphological features of differentiation. Introduction of chromosome 11 induced a more flattened and adherent morphology, with short neuritic processes, similar to the changes seen after a few days of growth in the presence of retinoic acid. As these microcell hybrids could be powerful models for the identification of candidate neuroblastoma suppressor or differentiation genes, we decided first to determine the genetic status of the chromosome 11 in the hybrid subclones prior to further experiments. To this purpose, the parental NGP cell line and the microcell hybrids after chromosome 11 transfer were analysed using high-resolution arrayCGH (microarray based comparative genomic hybridisation), FISH (fluorescence in situ hybridisation) and microsatellite heterozygosity mapping. Following the identification of a region on chromosome 11 with altered copy number, we measured the mRNA expression levels of genes in these regions in an attempt to find altered gene expression related to neurite outgrowth and differentiation.

\section{Results \\ Morphological characterisation}

The chromosome 11 status of the different microcell hybrid subclones used in this study and the reported chromosome 11 changes [10] are listed in Table 1. The morphology of the cells was comparable to the phenotype described by Bader and colleagues [10]. Cells of the parental cell line NGP.1A.TR1 (a tumour reconstitute of mutagenised NGP cells [10]) were non-adherent, spheroid and growing in cell clusters (Figure 1A). Subclones with an apparently intact transferred chromosome 11 (MCH574c4, c11, c13), as well as the clone with reported loss of a region on $11 \mathrm{q}(\mathrm{MCH} 574 \mathrm{c} 10)$ exhibited features of induced differentiation, with more flattened and adherent cells and some short neuritic processes (Figure 1C). Subclone MCH574c3 with reported loss of part of 11p showed the same non-adherent phenotype as the parental cell line NGP.1A.TR1 (Figure 1B).

Table I: Chromosome II status and morphology of the microcell hybrids (MCH) obtained after chromosome II transfer in parental NGP.IA.TRI cells as determined by Bader and colleagues [10] and in this study

\begin{tabular}{|c|c|c|c|}
\hline \multirow[t]{2}{*}{$\begin{array}{l}\text { microcell hybrid subclone } \\
\text { (NGP.IA.TRI + chr II) }\end{array}$} & \multicolumn{2}{|c|}{$\begin{array}{l}\text { chromosome II status } \\
\text { (in addition to parental NGP.IA.TRI I Iq-loss) }\end{array}$} & \multirow[t]{2}{*}{ morphology } \\
\hline & Bader et al. [10] & this study & \\
\hline $\mathrm{MCH} 574 \mathrm{c} 4, \mathrm{cl} \mathrm{I}, \mathrm{cl} 3$ & no additional changes & $\operatorname{del}(\mathrm{I} I)($ pterp I5.I) & $\begin{array}{l}\text { more flattened, adherent cells, } \\
\text { some short neuritic processes }\end{array}$ \\
\hline $\mathrm{MCH} 574 \mathrm{cl} 0$ & $\begin{array}{l}\operatorname{del}(\mathrm{II})(\mathrm{q} 23.3)(\mathrm{MCTI} 28 . \mathrm{I}, \mathrm{HBI} \\
\mathrm{I8P2})\end{array}$ & $\operatorname{del}(\mathrm{II})($ pterp I5.I) & $\begin{array}{l}\text { more flattened, adherent cells, } \\
\text { some short neuritic processes }\end{array}$ \\
\hline $\mathrm{MCH} 574 \mathrm{c} 3$ & $\operatorname{del}(I I)(p \mid 5.5)(H R A S)$ & $\begin{array}{l}\operatorname{del}(\mathrm{I} I)(\text { pterp I 5.I) } \\
\operatorname{del}(\mathrm{I} I) \text { (pterpI3) } \\
\operatorname{del}(\mathrm{I} I) \text { (q25qter) }\end{array}$ & $\begin{array}{l}\text { non-adherent, spheroid cells, } \\
\text { growing in cell clusters }\end{array}$ \\
\hline
\end{tabular}



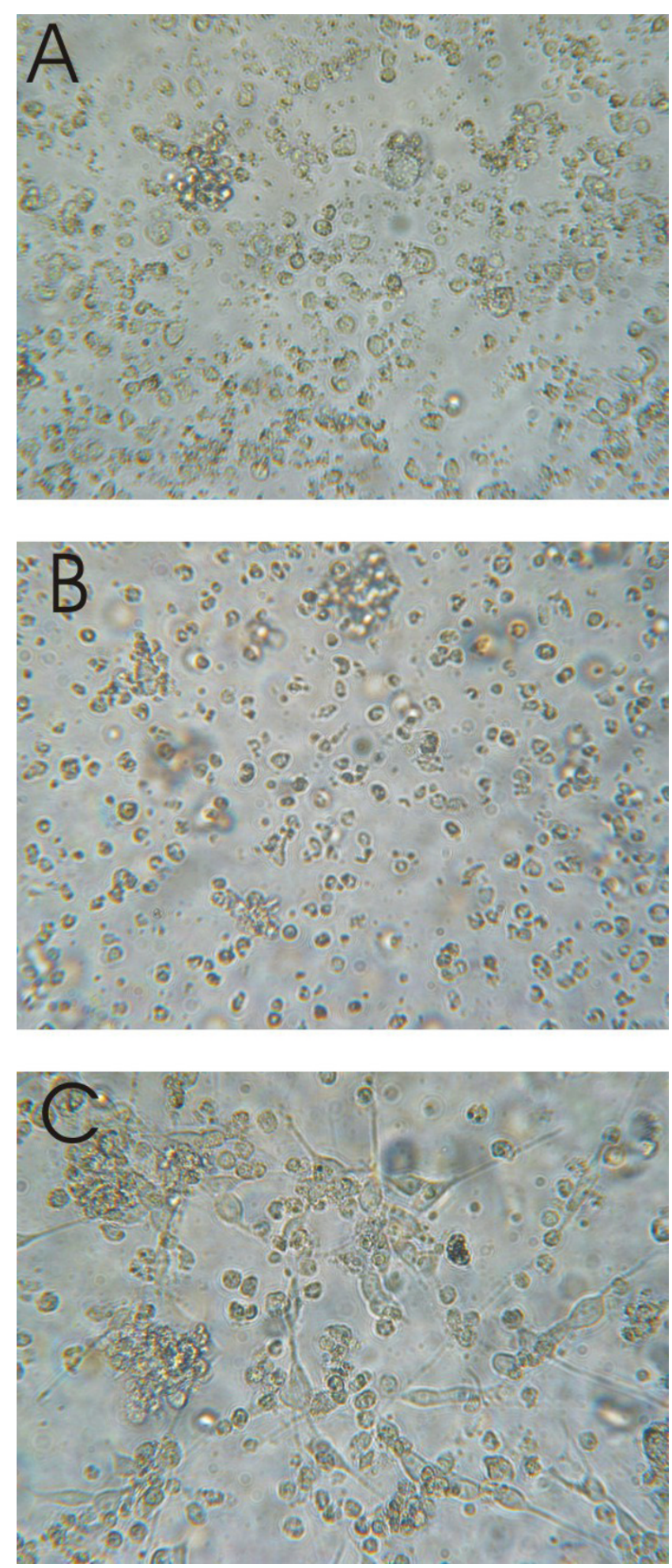

Figure I

Cell morphology of parental cell line NGP.IA.TRI (A) and chromosome II transferred subclone MCH574c3 (B) with non-adherent, spheroid cells, and subclone MCH574clO (C) showing signs of induced differentiation such as short neuritic processes
Assessment of the organisation of the actin fibres using phalloidin staining confirmed the presence of neurites (and excluded stress fibres) in subclones MCH574c10 and MCH574c11[11].

\section{ArrayCGH based chromosome I I copy number assessment} ArrayCGH was performed for NGP.1A.TR1, MCH574c3 and MCH574c10 cells. These hybridisations failed to provide evidence for the reported $11 \mathrm{q}$-deletion in the transferred chromosome of microcell hybrid MCH574c10 (Figure 2). Unexpectedly, the distal region of the short arm of one of the chromosomes 11 (11pter->11p15.1) was deleted in both $\mathrm{MCH} 574 \mathrm{c} 3$ and $\mathrm{MCH} 574 \mathrm{c} 10$. Microcell hybrid MCH574c3 presented with an additional larger deletion of 11 pter->11p13, as well as a third deletion involving the most distal band (11q25->11qter) in one of the chromosomes 11. Deletion of a single BAC clone RP11-51B23 on 11p15.3 was detected in the parental NGP.1A.TR1 cells (Figure 2B). Thus far, this clone has not been recognised as being involved in polymorphic genomic deletions for this particular chromosomal region (own observations and Ensembl clone list). Deletions observed by arrayCGH were confirmed by FISH analysis using one BAC clone selected in each observed deleted region (RP11-734D5 on 11p15.3, RP11-48O9 on 11p13, RP11-545G16 on 11q25). This FISH analysis demonstrated that the 11 pter->11p15.1 deletion was present in all other subclones that were not analysed with arrayCGH, i.e. MCH574c4, c11 and c13.

\section{Microsatellite heterozygosity mapping}

To determine which of the chromosomes 11 exhibited loss of the 11pter->11p15.1, 11pter->11p13 and 11q25$>11$ qter regions, microsatellite heterozygosity mapping in conjunction with FISH analysis of metaphase spreads was performed. Microsatellite markers D11S861 (on 11p15.2) and D11S1324 (on 11p14.1) were tested on NGP.1A.TR1, $\mathrm{MCH} 574 \mathrm{c} 3$ and MCH574c10. These tests show that one of the two parental chromosomes 11 had lost the 11 pter$>11$ p15.1 region, while the 11 pter->11p13 segment was lost in the transferred chromosome. FISH on metaphase spreads (clone RP11-545G16 on 11q25 in combination with RP11-206C1 on 11p15.1; clone RP11-709M17 on $11 \mathrm{q} 25$ in combination with clone RP11-4B7 on 11p15.2) demonstrated that the 11q25->11qter deletion occurred in the transferred chromosome 11 , whereas the 11 pter$>11$ p15.1 deletion occurred in the normal parental chromosome 11 (and not in the parental $\operatorname{der}(11) \mathrm{t}(2 ; 11)$ ) (Figure 2).

\section{Breakpoint delineation of chromosome II deletions}

The position of the deletion breakpoints was confirmed or refined by FISH analysis. The breakpoint of the del(11)(q22.1qter) resulting from an unbalanced translocation between chromosomes 2 and 11 in parental 
A NGP1A.TR1 parental
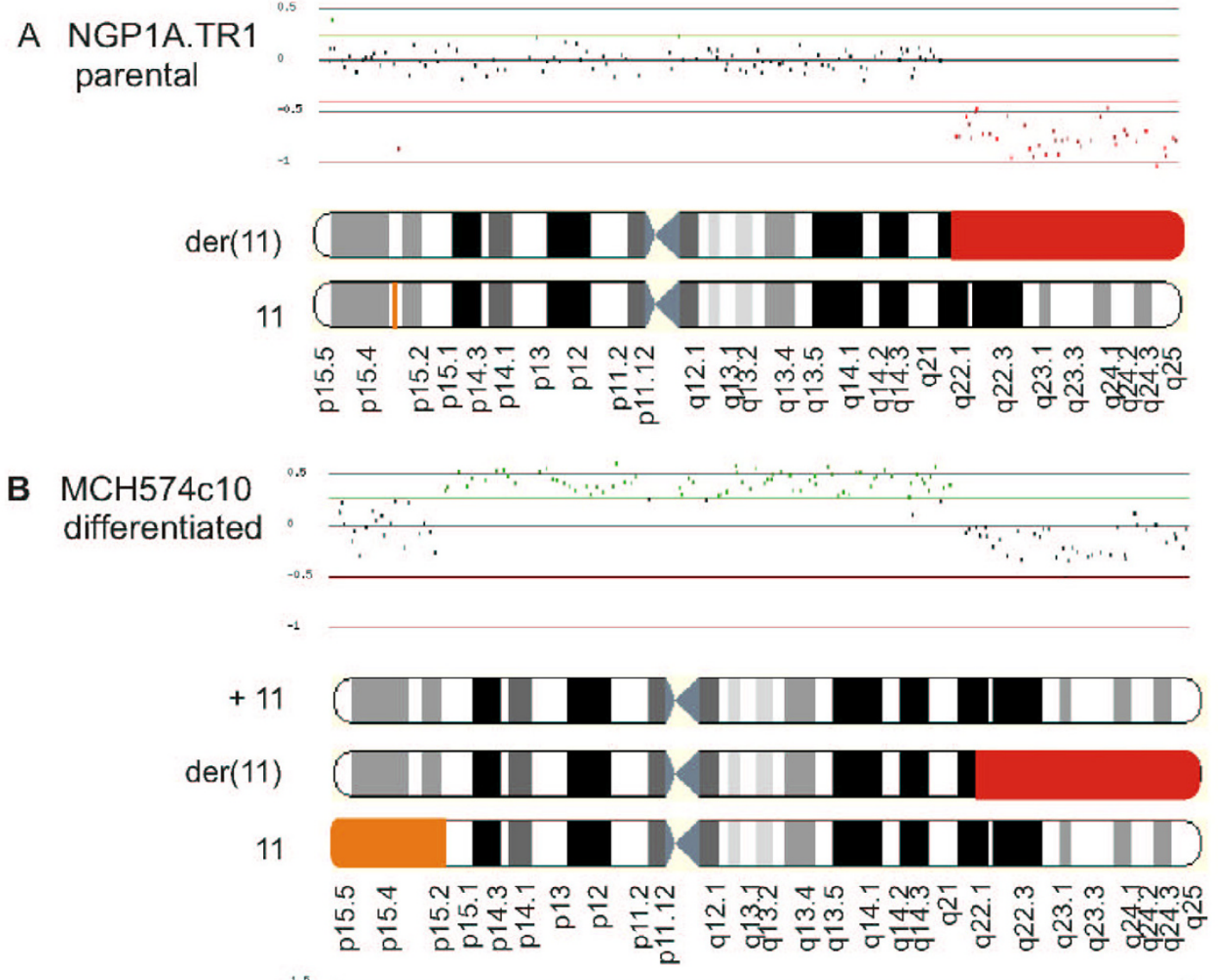

$\mathrm{MCH} 574 \mathrm{c} 3$
reversed

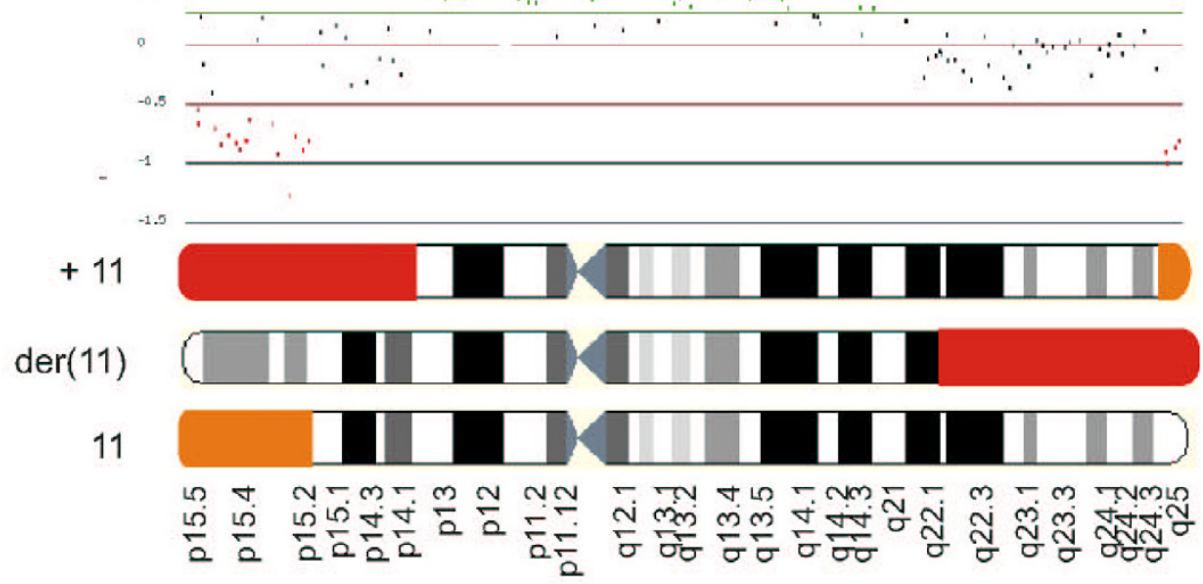

\section{Figure 2}

ArrayCGH results (log2 scale) of parental cell line NGPIA.TRI and microcell hybrids $\mathrm{MCH} 574 \mathrm{c} 3$ and MCH574cl0 compared to a normal female control, with reported (red) and newly detected (orange) chromosome II deletion events, (A) parental cell line (NGP.IA.TRI), (B) MCH574clO in which regional I I q-loss of the transferred chromosome II was reported [I0] and (C) $\mathrm{MCH} 574 \mathrm{c} 3$ with reported regional II -loss of transferred chromosome II. FISH was used to confirm the results obtained by arrayCGH (data not shown). 

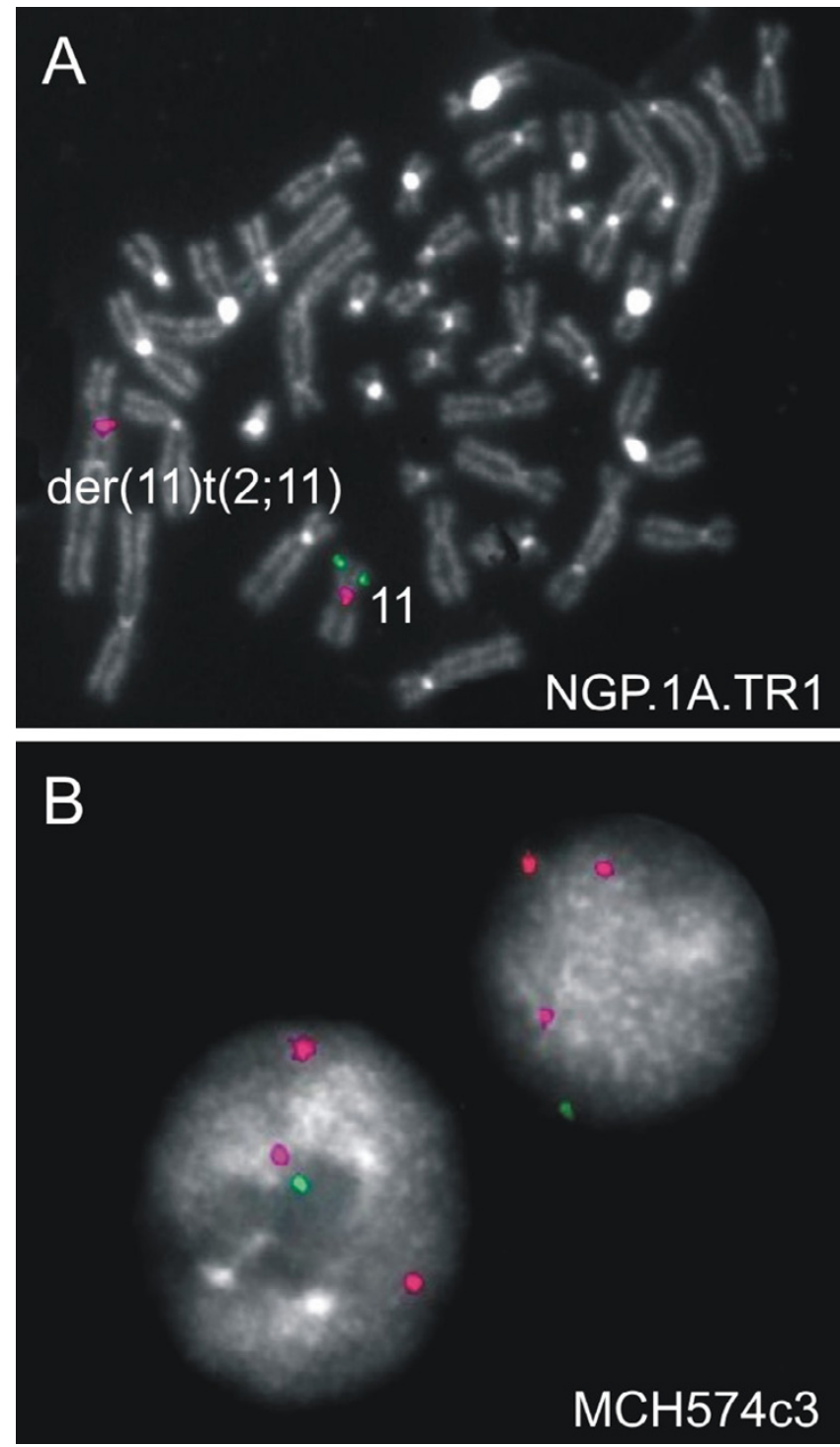

Figure 3

FISH analysis of BAC clones RPI I-573EI I (panel A), RPI I5 IB23 and RPII-47JI7 (not shown) in parental cells NGP.IA.TRI (with a derivative chromosome II, due to an unbalanced translocation between chromosomes II and 2) confirms the existence of a small deletion in IIpI5.3. The breakpoint of the distal I I q25-> I I qter deletion of the transferred chromosome in subclone $\mathrm{MCH} 574 \mathrm{c} 3$ was mapped between BAC clones RPI I-340LI 3 (not shown) and RPI I697E I 4 (panel B).

cell line NGP.1A.TR1 mapped within a 2.285 Mb segment located between BAC clones RP11-379J13 and RP1149M9 (map position between 97.328 Mb and 99.613 Mb, NCBI 35 May 2004 assembly (hg17)). The breakpoint of the 11 pter->11p15.1 deletion of the normal parental chromosome 11 in all microcell hybrids was assigned to a $229 \mathrm{~kb}$ segment between RP11-452G18 and RP11$358 \mathrm{H} 18$ (17.337 Mb - 17.596 Mb). The breakpoint of the larger 11p-deletion (11pter->11p13) present in $\mathrm{MCH} 574 \mathrm{c} 3$ was located within a $921 \mathrm{~kb}$ segment flanked by clones RP11-48O9 and RP11-202M19 (33.038 Mb $33.959 \mathrm{Mb})$. The breakpoint of the distal $\pm 13 \mathrm{Mb} 11 \mathrm{q} 25-$ $>11$ qter deletion of the transferred chromosome in subclone MCH574c3 was mapped between BAC clones RP11-340L13 and RP11-697E14 (131.149 Mb - 131.230 $\mathrm{Mb})$. Flanking clones of the $11 \mathrm{p} 15.3$ deletion in NGP.1A.TR1 were also tested using FISH (RP11-734D5, RP11-573E11, RP11-47J17) demonstrating that the deletion involves at least a $707 \mathrm{~kb}$ segment including BAC clones RP11-573E11 and RP11-47J17 (12.202 Mb 12.909 Mb) (Figure 3).

\section{mRNA expression profiling}

As loss of $11 \mathrm{q}$ is a recurrent chromosomal aberration in a subgroup of advanced stage neuroblastomas, the 11q25$>11$ qter region that is deleted in the $\mathrm{MCH} 574 \mathrm{c} 3$ microcell hybrid is of particular interest. In an attempt to relate the observed morphology of induced neuronal differentiation to expression differences of genes located in this distal 11q25 segment, the expression of 6 known genes, i.e. HNT, OPCML, JAM3, THY28, ACAD8 and B3GAT1 was tested. Of particular interest are HNT and B3GAT1, because of their reported involvement in neurite outgrowth and neural crest development. We quantified the mRNA expression of these 6 genes in the microcell hybrids, the parental cell line and in neuroblastoma cell lines (SH-SY5Y, LA-N-5 and NTRK1 transfected SH-SY5Y) that were treated with inducers of differentiation [12-14]. While the expression of the genes is not significantly altered in the microcell hybrids compared to the parental cell line, the expression of HNT is significantly higher in different cell lines that are induced to differentiate (between 5 to 120 fold induction) (Figure 4).

\section{Discussion}

In a search for candidate neuroblastoma genes located on chromosome arm 11q, we investigated microcell hybrids obtained by transfer of a normal chromosome 11 into NGP neuroblastoma cells with loss of 11q. Although initially designed as a control experiment, this transfer resulted in morphological changes in the obtained hybrids (without loss of tumorigenicity) and also yielded revertants after further culture [10]. The induced differentiation that was observed in all but one microcell hybrid is consistent with the presence of a neuroblastoma differentiation gene on chromosome 11 . We thus anticipated that these hybrids might be of interest for functional mapping of the regions on chromosome 11 critically involved in neuroblastoma pathogenesis. To investigate this, we performed arrayCGH copy number analysis of these 


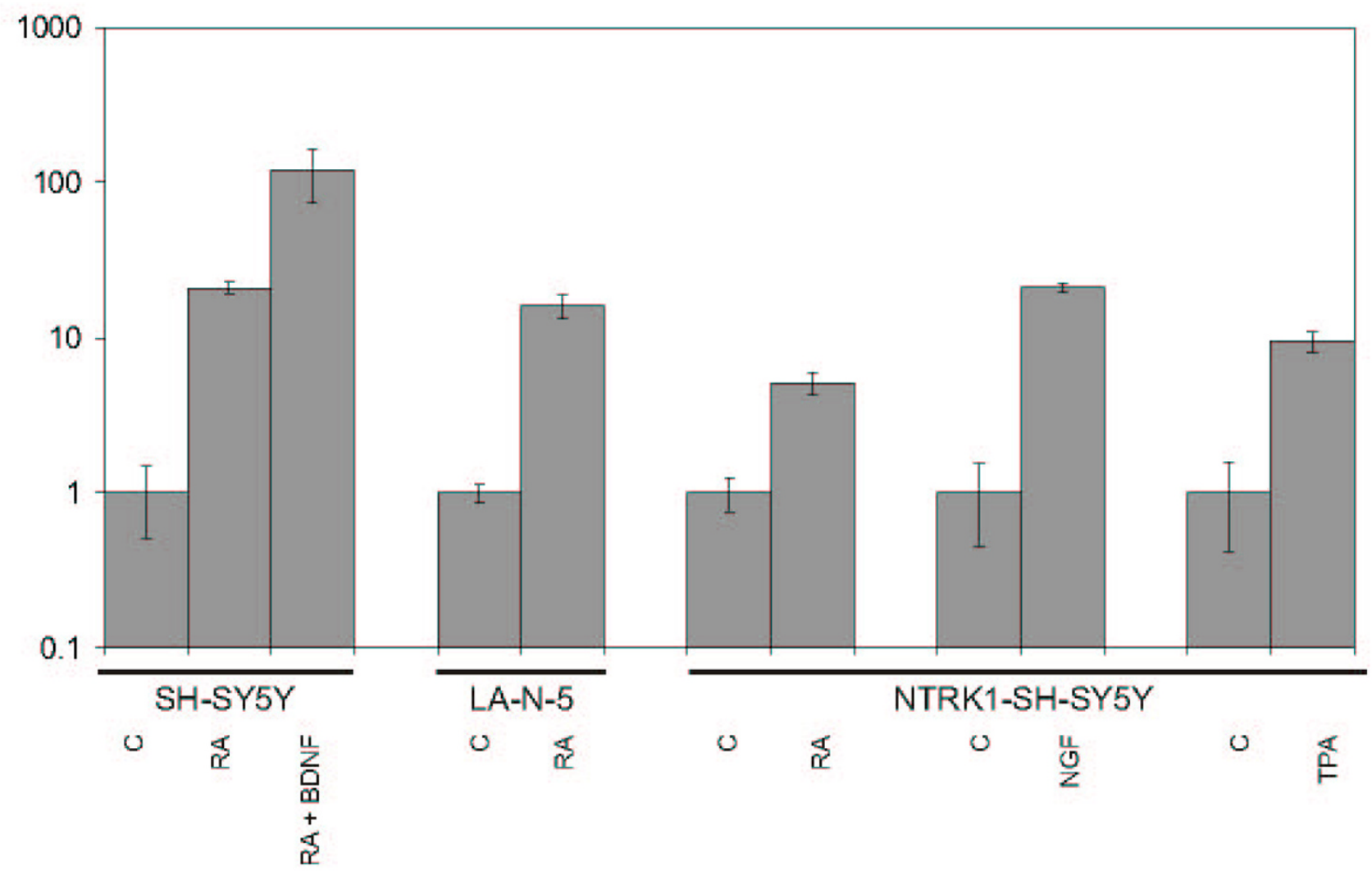

\section{Figure 4}

Fold induction of HNT mRNA expression (log scale, versus control cultures, C) in neuroblastoma cell lines SH-SY5Y, LA-N-5 and NTRKI-transfected SH-SY5Y after induction of differentiation with RA and BDNF (retinoic acid and brain-derived neurotrophic factor), NGF (nerve growth factor) and TPA (12-O-tetradecanoyl-phorbol-I3-acetate).

microcell hybrids. This allowed us to assess the status of the introduced (and parental) chromosomes 11 and to validate these hybrids as model system for further functional assays. The obtained results were surprising and puzzling. One particular microcell hybrid that did not show the expected differentiation features upon chromosome 11 transfer was shown to carry an 11q25->11qter deletion in the transferred chromosome. In addition we found that all microcell hybrid subclones presented with an 11pter->11p15.1 deletion, and that the MCH574c3 hybrids presented with an additional 11pter->11p13 deletion.

In line with previous successful functional analyses of microcell hybrids [15], the responsible gene for the observed changes in cell morphology is assumed to be located in one of the chromosomal regions that show a different copy number in the microcell hybrid subclones with differentiation features (MCH574c4, c10, c11 and c13) compared to the non-adherent, spheroid cell phenotype of parental cell line NGP.1A.TR1 and microcell hybrid subclone MCH574c3. Based upon our findings three regions can be identified as candidate regions harbouring a putative differentiation gene: (1) the 11q25$>11$ qter region (lost in MCH574c3), (2) the 11p13$>11 \mathrm{p} 15.1$ region (lost in $\mathrm{MCH} 574 \mathrm{c} 3$ but not in the other MCH574 subclones) and (3) a small region of at least 706 kb on 11p15.3 (lost in NGP.1A.TR1) (Figure 5).

As loss of distal $11 \mathrm{q}$ is a recurrent chromosomal aberration in MYCN single copy advanced stage neuroblastomas [3], we propose the 11q25->11qter chromosomal segment as the most likely candidate region for the presence of a differentiation gene. Despite efforts to define a shortest region of overlap (SRO) for 11q-loss in neuroblastoma by microsatellite heterozygosity mapping [7] and delineation of constitutional 11q-deletions $[8,16]$, a consensus region for loss of $11 \mathrm{q}$ in neuroblastoma has not 
A B $\quad$ C

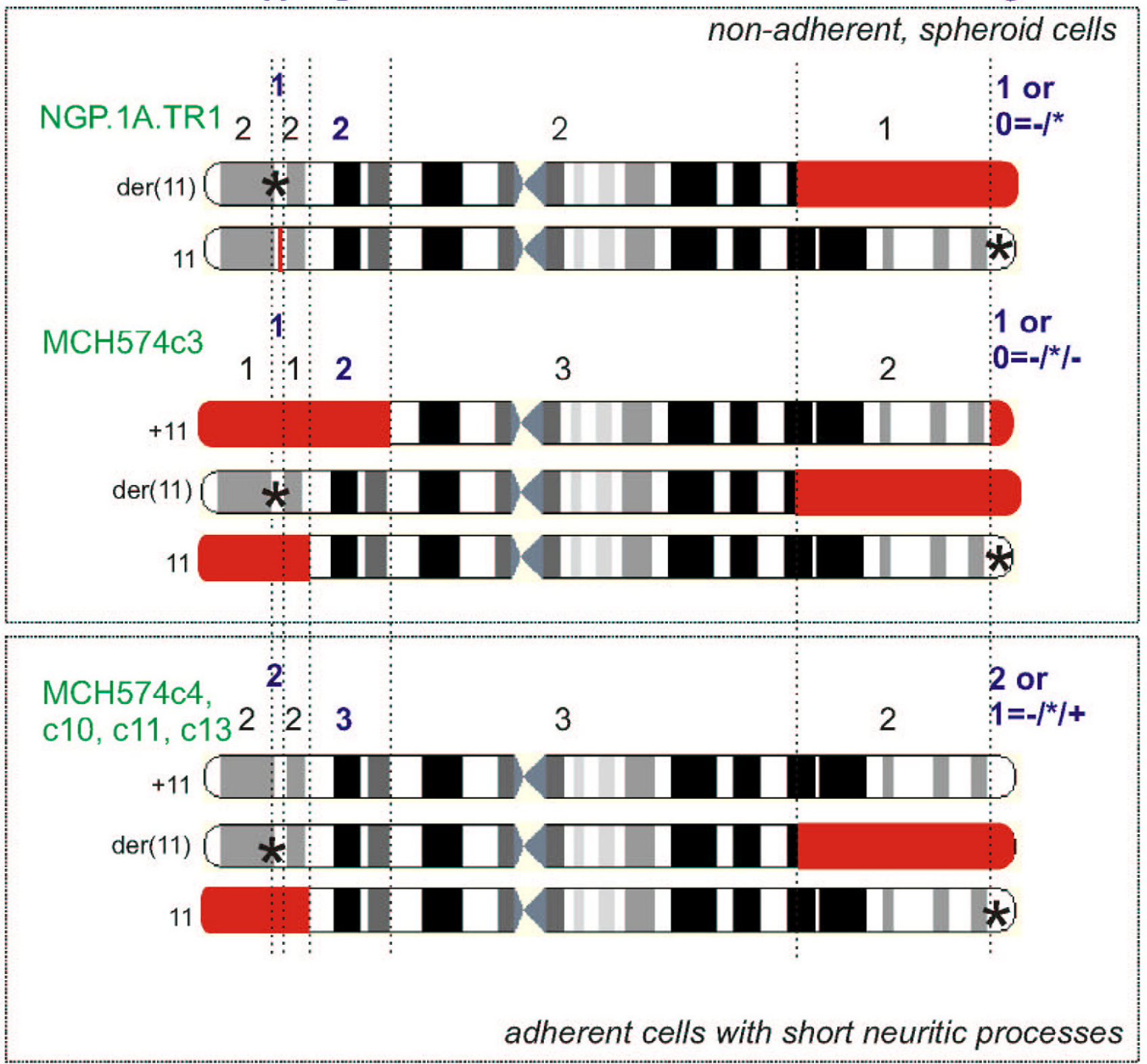

Figure 5

Regional copy numbers (deletion events are indicated in red) in cells with non-adherent, spheroid (parental) cell phenotype compared to cells with induced differentiation, demonstrating the three regions on chromosome II that may be involved in the phenotypic difference, i.e. a small region on I I I 5.3 encompassing BAC clone RPII-5IB23 (lost in NGP. IA.TRI) (A region), the IIpI3->IIPI5.I region (lost in $\mathrm{MCH} 574 \mathrm{c} 3$ but not in the other MCH574 microcell hybrids) (B region) and the I I 25-> I I qter region (lost in $\mathrm{MCH} 574 \mathrm{c3}$ ) (C region) (* indicates the putative presence of a mutated gene).

been defined thus far. In the light of the uncertainty of the boundaries of the $11 \mathrm{q}$ SRO, the $11 \mathrm{q} 25->11 \mathrm{qter}$ region must be considered as potentially harbouring a neuroblastoma suppressor or differentiation gene. This region is present in two copies in microcell hybrid subclones MCH574c4, c10, c11 and c13 with differentiated morphology, but only in one copy in the non-adherent, spheroid cells from NGP.1A.TR1 and MCH574c3. Six known 
genes, i.e. HNT, OPCML, JAM3, THY28, ACAD8 and B3GAT1 are located in this distal $11 \mathrm{q}$ segment, of which two genes are of particular interest. HNT (neurotrimin) is reported to promote neurite outgrowth and adhesion [17]. B3GAT1 encodes for a protein that functions as the key enzyme in a glucuronyl transfer reaction during the biosynthesis of the carbohydrate epitope HNK1 (CD57) $[18,19]$, which is a carbohydrate expressed in developmentally immature neural crest cells [20]. Interestingly, the expression of HNT is significantly increased in neuroblastoma cell lines that are induced to differentiate using RA (retinoic acid), RA plus BDNF (brain-derived neurotrophic factor), NGF (nerve growth factor) and TPA (12-O-tetradecanoyl-phorbol-13-acetate). However, HNT expression is not significantly different between the differentiated microcell hybrids and the parental cells. It is conceivable that the observed phenotypic changes are caused by small changes in expression that can not be reliably detected by Q-PCR. An alternative explanation is that the normal parental chromosome 11 harbours a mutated allele that is normally expressed at the mRNA level (Figure 5 ). Reintroduction of a wild type allele by chromosome transfer could repair the defect, leading to differentiation. This is in keeping with reversal to the non-adherent, spheroid morphology of the microcell hybrids that have lost the 11q25->11qter region of the transferred chromosome. Additional mutation, promoter hypermethylation and gene directed functional assays are needed to clarify which of the genes located within the deleted 11q25->11qter region are responsible for the differentiated phenotype.

While the $11 \mathrm{q} 25$ region is the best candidate region to harbour a differentiation gene, the observed deletions on the short arm of chromosome 11 may also account for the differentiated morphology. The observation of two independent deletion events along the distal part of chromosome arm 11p is suggestive for the involvement of this region. In particular, it is striking that all microcell hybrids in which chromosome 11 is transferred are characterised by the presence of an 11pter->11p15.1 deletion in the (prior to transfer) normal parental chromosome 11. This may either be the result of an early coincidental event during the transfer process, or indicative for a selection process against the presence of three copies of a growth suppressive gene in this region. The last hypothesis may be further supported by the presence of unbalanced $11 \mathrm{p}$ deletions in $4 \%$ of neuroblastomas $(14 / 394)[21,22]$.

Apart from highlighting at candidate $11 \mathrm{q}$ regions involved in neuroblastoma pathogenesis, this study clearly shows that it is important to monitor the transfer of the desired chromosome, as well as the genetic background of the cell line before and after chromosome transfer experiments. Selective pressure processes may occur during or after transfer of a chromosome, e.g. by chromosomal loss in order to maintain the viability of the microcell hybrids. Hence, detailed information on the chromosome copy number status before and after transfer is required in order to correlate phenotypic changes with chromosomal alteration. ArrayCGH has been proven to be a valuable screening method for evaluation of the chromosome alterations and for delineation of possible deletion events, allowing fine-mapping of the candidate regions that harbour candidate suppressor genes.

\section{Conclusion}

Microsatellite marker heterozygosity analysis, FISH and (array)CGH based copy number in neuroblastoma tumour specimens and patients with constitutional deletions have thus far not identified a consensus SRO for 11q-deletion. Here, we present an alternative strategy to pinpoint chromosomal regions or genes that may be important in neuroblastoma pathogenesis. Chromosome 11 transfer, followed by phenotype scoring and high-resolution copy number analysis delineated putative regions on chromosome 11 involved in tumour differentiation. Further mutation and functional analyses are required to clarify the putative involvement of genes localised in these regions in neuroblastoma.

\section{Methods \\ Cell lines}

The parental cell line, NGP.1A.TR1, and the chromosome 11 microcell transfer derived subclones MCH574c3, c4, c10, c11 and c13 used in this study have been described previously [10].

Cell lines were cultured following standard procedures and were digitally photographed under an inverted (phase-contrast) microscope, pelleted, snap-frozen and stored at $-80^{\circ} \mathrm{C}$ for further processing. DNA was isolated using the QIAamp DNA mini kit (Qiagen). RNA was isolated from the snap-frozen cell pellets using the RNeasy Mini kit (Qiagen) according to the manufacturer's guidelines, followed by RNase free DNase treatment on column (Qiagen).

Culture conditions and details regarding differentiation protocols are given in $[12,13]$. The NTRK1-transfected SHSY5Y cells used, were SH-SY5Y/trkA, clone 6:2 described in [23].

\section{Phalloidin staining}

Cell lines were fixed for $10 \mathrm{~min}$ in $4 \%$ paraformaldehyde/ HEPES on ice. The excess of aldehydes is quenched for 5 min in $50 \mathrm{mM} \mathrm{NH}_{4} \mathrm{Cl}$. After washing twice for $5 \mathrm{~min}$ in $1 \mathrm{x}$ PBS, extraction is performed for $5 \mathrm{~min}$ in acetone $\left(20^{\circ} \mathrm{C}\right)$. The cells are washed again twice for $5 \mathrm{~min}$ in $1 \mathrm{x}$ PBS, followed by blocking in $0.2 \%$ Fish Skin Gelatine (FSG, Sigma)/PBS. During $60 \mathrm{~min}$ cells are incubated with Alexa 
594-phalloidin (1 unit per section), dissolved in $0.2 \% \mathrm{FSG} / \mathrm{PBS}$ at $37^{\circ} \mathrm{C}$. Cells are washed twice for $5 \mathrm{~min}$ in 1x PBS; nuclei are stained for 1 min with DAPI; sections are washed with 1x PBS and mounted in Vectashield.

\section{ArrayCGH}

ArrayCGH using $1 \mathrm{Mb}$ BAC arrays was performed once for NGP.1A.TR1, MCH574c3 and MCH574c10 cells with normal female DNA as control. In addition, subclones MCH574c3 and MCH574c10 were hybridised to the same arrays with NGP.1A.TR1 DNA as control. Hybridisation of cell line and control DNA to the array was performed as described [24]. Using our in-house developed analysis and visualisation software, arrayCGHbase, data were normalised to the median ratio, and replicate median ratio profiles visualised http://medgen.ugent.be/arrayCGH base [29].

\section{FISH and microsatellite marker analysis}

BAC clones and microsatellite markers were selected based on their chromosomal position using the Ensembl genome browser http://www.ensembl.org, the UCSC human genome browser (July 2003 freeze, http:// genome.ucsc.edu) or the Genome Database http:// gdbwww.gdb.org. Labelling and FISH (fluorescence in situ hybridisation) was performed as described [25]. Experimental conditions for the fluorescent based microsatellite screening can be obtained from the authors upon request.

\section{Real-time quantitative RT-PCR based mRNA expression profiling}

Primers were designed using Primer Express v2.0 (Applied Biosystems). Primer sequences are available in the public RTPrimerDB database http://medgen.UGent.be/ rtprimerdb/: HNT (1078), OPCML (1079), JAM3 (1080), THY28 (1084), ACAD8 (1081), B3GAT1 (1082), HPRT1 (5), UBC (8) and GAPD (3) [26]. Relative expression levels were determined using an optimized two-step SYBR Green I RT-PCR assay [27]. PCR reagents were obtained from Eurogentec as SYBR Green I core reagents, prepared as $2 \mathrm{x}$ mastermixes, stored at $-20^{\circ} \mathrm{C}$ and used according to the manufacturer's instructions. Reactions were run on an ABI5700 (Applied Biosystems). The comparative $\mathrm{C}_{\mathrm{T}}$ method was used for quantification. Gene expression levels were normalized using the geometric mean of the 3 most stable internal control genes in neuroblastoma (i.e. UBC, HPRT1 and GAPD) as reported previously [28].

\section{Abbreviations}

arrayCGH = microarray based comparative genomic hybridisation

FISH = fluorescence in situ hybridisation
MMCT $=$ microcell mediated chromosome transfer

$\mathrm{SRO}=$ shortest region of overlap

\section{Authors' contributions}

KDP supervised the culturing of the microcell hybrids that were produced by SB, carried out the microsatellite marker analysis and drafted the manuscript. PC performed the arrayCGH hybridisations, under the supervision of HF and NC. KDP and BM analysed the arrayCGH data. WW performed the phalloidin staining and NVR evaluated the FISH results. NY performed real-time quantitative PCR. Neuroblastoma cells were induced to differentiate by AE under the supervision of SP. JV and FS participated in the study design and coordination, and were the final editors of the manuscript.

\section{Acknowledgements}

We greatly acknowledge Peter Degrave and Geert De Vos for the cell cultures, Anouck Waeytens and Isabel Rottiers for phalloidin staining, and Helén Nilsson for providing us with RNA from NTRKI-SH-SY5Y cells that were treated with differentiation inducers.

This text presents research results of the Belgian program of Interuniversity Poles of Attraction initiated by the Belgian State, Prime Minister's Office, Science Policy Programming. The scientific responsibility is assumed by the authors. KDP, JV and WW are supported by a post-doctoral grant from the Institute for the Promotion of Innovation by Science and Technology in Flanders (IWT). NVR is a post-doctoral researcher with the FWO. This work was supported by FWO-grant G.0028.00, VEO-grant 0 I IVI 302 , BOF-grant OI IFI 200 and OI IB4300, and GOA-grant I205 I 203.

\section{References}

I. Vandesompele J, Van Roy N, Van Gele M, Laureys G, Ambros P, Heimann P, Devalck C, Schuuring E, Brock P, Otten J, Gyselinck J, De Paepe A, Speleman F: Genetic heterogeneity of neuroblastoma studied by comparative genomic hybridization. Genes Chromosomes Cancer 1998, 23(2): I4I-I52.

2. Vandesompele J, Speleman F, Van Roy N, Laureys G, Brinskchmidt C Christiansen H, Lampert F, Lastowska M, Bown N, Pearson A, Nicholson JC, Ross F, Combaret V, Delattre O, Feuerstein BG, Plantaz D: Multicentre analysis of patterns of DNA gains and losses in 204 neuroblastoma tumors: how many genetic subgroups are there? Med Pediatr Oncol 200I, 36(I):5-10.

3. Plantaz D, Vandesompele J, Van Roy N, Lastowska M, Bown N, Combaret V, Favrot MC, Delattre O, Michon J, Benard J, Hartmann O, Nicholson JC, Ross FM, Brinkschmidt C, Laureys G, Caron H, Matthay KK, Feuerstein BG, Speleman F: Comparative genomic hybridization (CGH) analysis of stage 4 neuroblastoma reveals high frequency of IIq deletion in tumors lacking MYCN amplification. Int J Cancer 200I, 9 I (5):680-686.

4. Luttikhuis ME, Powell JE, Rees SA, Genus T, Chughtai S, Ramani P, Mann JR, McConville CM: Neuroblastomas with chromosome I lq loss and single copy MYCN comprise a biologically distinct group of tumours with adverse prognosis. $\mathrm{Br} J$ Cancer 200I, 85(4):53I-537.

5. Breen CJ, O'Meara A, McDermott M, Mullarkey M, Stallings RL: Coordinate deletion of chromosome $3 p$ and I Iq in neuroblastoma detected by comparative genomic hybridization. Cancer Genet Cytogenet 2000, I 20( I):44-49.

6. Vandesompele J, Baudis M, De Preter K, Van Roy N, Ambros P, Bown N, Brinkschmidt C, Christiansen H, Combaret V, Lastowska M, Nicholson J, O'Meara M, Plantaz D, Stallings R, Brichard B, Van den Broecke C, De Paepe A, Laureys G, Speleman F: Unequivocal delineation of clinico-genetic subgroups and development of 
a new model for outcome prediction in neuroblastoma. J Clin Oncol 2005, 23(10):2280-99. submitted

7. Guo C, White PS, Weiss MJ, Hogarty MD, Thompson PM, Stram DO, Gerbing R, Matthay KK, Seeger RC, Brodeur GM, Maris JM: Allelic deletion at Ilq23 is common in MYCN single copy neuroblastomas. Oncogene 1999, I 8(35):4948-4957.

8. Mosse Y, Greshock J, King A, Khazi D, Weber BL, Maris JM: Identification and high-resolution mapping of a constitutional I Iq deletion in an infant with multifocal neuroblastoma. Lancet Oncol 2003, 4(I 2):769-77I.

9. De Preter K, Vandesompele J, Hoebeeck J, Vandenbroecke C, Smet J, Nuyts A, Laureys G, Combaret V, Van Roy N, Roels F, Van Coster R, Praet M, De Paepe A, Speleman F: No evidence for two-hit involvement of SDHD in neuroblastoma pathogenesis. $B M C$ Cancer 2004, 4(I):55.

10. Bader SA, Fasching C, Brodeur GM, Stanbridge Ej: Dissociation of suppression of tumorigenicity and differentiation in vitro effected by transfer of single human chromosomes into human neuroblastoma cells. Cell Growth Differ I991, 2(5):245-255.

II. Ling M, Troller U, Zeidman R, Lundberg C, Larsson C: Induction of neurites by the regulatory domains of PKCdelta and epsilon is counteracted by PKC catalytic activity and by the RhoA pathway. Exp Cell Res 2004, 292(I): I35-I50.

12. Edsjo A, Hallberg B, Fagerstrom S, Larsson C, Axelson H, Pahlman S: Differences in early and late responses between neurotrophin-stimulated trkA- and trkC-transfected SH-SY5Y neuroblastoma cells. Cell Growth Differ 200I, I 2(I):39-50.

13. Edsjo A, Lavenius E, Nilsson H, Hoehner JC, Simonsson P, Culp LA, Martinsson T, Larsson C, Pahlman S: Expression of trkB in human neuroblastoma in relation to MYCN expression and retinoic acid treatment. Lab Invest 2003, 83(6):8I3-823.

14. Sidell N: Retinoic acid-induced growth inhibition and morphologic differentiation of human neuroblastoma cells in vitro. $J$ Natl Cancer Inst 1982, 68(4):589-596.

15. Doherty AM, Fisher EM: Microcell-mediated chromosome transfer (MMCT): small cells with huge potential. Mamm Genome 2003, 14(9):583-592

16. Satge D, Moore SW, Stiller CA, Niggli FK, Pritchard-Jones K, Bown $\mathrm{N}$, Benard J, Plantaz D: Abnormal constitutional karyotypes in patients with neuroblastoma: a report of four new cases and review of 47 others in the literature. Cancer Genet Cytogenet 2003, I 147(2):89-98.

17. Gil OD, Zanazzi G, Struyk AF, Salzer JL: Neurotrimin mediates bifunctional effects on neurite outgrowth via homophilic and heterophilic interactions. J Neurosci 1998, 18(22):9312-9325.

18. Mitsumoto $\mathrm{Y}$, Oka S, Sakuma H, Inazawa J, Kawasaki T: Cloning and chromosomal mapping of human glucuronyltransferase involved in biosynthesis of the HNK-I carbohydrate epitope. Genomics 2000, 65(2):166-173.

19. Marcos I, Galan JJ, Borrego S, Antinolo G: Cloning, characterization, and chromosome mapping of the human GIcAT-S gene. J Hum Genet 2002, 47( I 2):677-680.

20. Bronner-Fraser M: Analysis of the early stages of trunk neural crest migration in avian embryos using monoclonal antibody HNK-I. Dev Biol 1986, I I 5(I):44-55.

21. Guo C, White PS, Hogarty MD, Brodeur GM, Gerbing R, Stram DO, Maris JM: Deletion of I I q23 is a frequent event in the evolution of MYCN single-copy high-risk neuroblastomas. Med Pediatr Oncol 2000, 35(6):544-546.

22. Schleiermacher G, Janoueix-Lerosey I, Combaret V, Derre J, Couturier J, Aurias A, Delattre O: Combined 24-color karyotyping and comparative genomic hybridization analysis indicates predominant rearrangements of early replicating chromosome regions in neuroblastoma. Cancer Genet Cytogenet 2003, I 4 I ( I):32-42.

23. Lavenius E, Gestblom C, Johansson I, Nanberg E, Pahlman S: Transfection of TRK-A into human neuroblastoma cells restores their ability to differentiate in response to nerve growth factor. Cell Growth Differ 1995, 6(6):727-736.

24. Fiegler H, Carr P, Douglas EJ, Burford DC, Hunt S, Scott CE, Smith J, Vetrie D, Gorman P, Tomlinson IP, Carter NP: DNA microarrays for comparative genomic hybridization based on DOP-PCR amplification of BAC and PAC clones. Genes Chromosomes Cancer 2003, 36(4):36I-374.
25. Van Roy N, Laureys G, Cheng NC, Willem P, Opdenakker G, Versteeg R, Speleman F: I; 17 translocations and other chromosome 17 rearrangements in human primary neuroblastoma tumors and cell lines. Genes Chromosomes Cancer 1994, 10(2): $103-114$.

26. Pattyn F, Speleman F, De Paepe A, Vandesompele J: RTPrimerDB: the real-time PCR primer and probe database. Nucleic Acids Res 2003, 31(1): I22-123.

27. Vandesompele J, De Paepe A, Speleman F: Elimination of primerdimer artifacts and genomic coamplification using a twostep SYBR green I real-time RT-PCR. Anal Biochem 2002, 303(I):95-98

28. Vandesompele J, De Preter K, Pattyn F, Poppe B, Van Roy N, De Paepe A, Speleman F: Accurate normalization of real-time quantitative RT-PCR data by geometric averaging of multiple internal control genes. Genome Biol 2002, 3(7):RESEARCH0034.

29. Menten B, Pattyn K, Robbrecht P, Michels E, Buysse K, Speleman F, Mortier G, De Paepe A, van Vooren S, Vermeesch J, Moreau Y, De Moor B, Vermeulen S, Speleman F, Vandesompele J: arrayCGHbase: an analysis platform for comparative genomic hybridization microarrays. BMC Bioinformatics 2005, 6(I): 124.
Publish with BioMed Central and every scientist can read your work free of charge

"BioMed Central will be the most significant development for disseminating the results of biomedical research in our lifetime. "

Sir Paul Nurse, Cancer Research UK

Your research papers will be:

- available free of charge to the entire biomedical community

- peer reviewed and published immediately upon acceptance

- cited in PubMed and archived on PubMed Central

- yours - you keep the copyright 